\title{
TAXONOMICAL IDENTIFICATION OF LEGUMINOCEOCARPON SINGHPURII GEN. ET. SP. NOV. FROM THE DECCAN INTERTRAPPEAN BEDS OF SINGHPUR M.P. IN INDIA.
}

\author{
MESHRAM S. M1., PANDEY I. J2., MOHTURE V.M³ \\ 1. Department of Botany, M.B. Patel College Sakoli. Dist. Bhandara. MS \\ 2. Department of Botany, C.J. Patel College Tirora, Dist. Gondia \\ 3. Department of Botany Rashtrapita Mahatma Gandhi Arts and Science College \\ Nagbhir Dist. Chandrapur \\ sanjaymeshram83@,rediffmail.com
}

Communicated : 27.12.19

Revision : 15.01 .2020

Accepted : 28.01 .2020
Published: 30.01 .2020

\begin{abstract}
:
A well preserved dicot fruit was collected from Singhpur (Lat $21^{\circ}, 30^{\prime}$ to $22^{\circ}, 55^{\prime} \mathrm{N}$ and Long $78^{\circ}, 15$ to $79^{\circ}, 20 \mathrm{E}$ ) in Chhindwara District, M.P. The present fossil specimen is a small indehiscent single seeded, legume fruit, ovule hemianatropus. The fruit is more or less spherical and broad in the middle portion. The fruit wall shows cellular differentiations in the pericarp region. The fruit though shows some characters of the present day families like Primulaceae, Malpighiaceae, Cruciferae, Capparidaceae, Crassulaceae, Leguminosae. It has close affinities with the members of the family Leguminosae. It could not conclusively be traced to any particular genus but it broadly placed under Leguminosae.
\end{abstract}

Key words: - Dicot fruit, Indehicent, Leguminosae Deccan Intertrappean, M.P.India.

\section{INTRODUCTION:}

The present specimen deals with the investigation of a new unilocular fossil dicotyledonous fruit reported from the Deccan Intertrappean beds of Singhpur, M. P. India.

The present investigation deals with a leguminous fruit. So far very few leguminous fruits have been reported from these beds. Carter (1854) reported leaf lets and fruits of Acacia and Cassia from the Deccan Intertrappean beds of Worli Bombay. Bicarpelocarpon singhpurii (Bhowal and Sheikh, 2008), Portulacaceocarpon jamsavlli (Meshram, Narkhede and Bhowal, 2011), Lagerstromiocarpon harissii ( Kokate 2013), Tiliaceaeocarpon jamsavlii ( Meshram, Narkhede and Bhowal, 2013), Pentaloculocarpon intertrappea (Khursel and Narkhede, 2016), Drupaceocarpon sahnii (Nandeshwar and Narkhede, 2016), Portulacaceocarpon bhuterwncis (Borkar and Nagrale), Tamaricaceocarpon mohgaonse, ( Yadav 2017 ), from the Madhyapradesh respectively. Some indehiscent fruits that have been reported from Deccan intertrapps are as under.

\section{MATERIAL AND METHODS:-}

The fossiliferous cherts collected from Singhpur beds show single specimen of unilocular fruit exposed in transverse plane. After etching the chert with hydrofluoric acid, peel sections were taken serially for investigation of the fruit.

\section{Description}

\section{Morphology of fruit}

The present fossil specimen is a small indehiscent single seeded, legume fruit, ovule hemianatropus. The fruit is more or less spherical and broad in the middle portion. (Text Fig - 28) Fruit measurse about $3.2 \mathrm{~mm}$ in diameter. The fruit wall shows cellular differentiations in the pericarp region. Fruit wall measure about 0.4mm. ( Plate 1, Figs.-1, 2)

\section{Anatomy of Fruit}

Fruit Wall: 
The fruit wall is well preserved without any scales or hairs. The pericarp of the fruit is $0.4 \mathrm{~mm}$ to $0.5 \mathrm{~mm}$ in thickness. It is multilayered and differentiated into three layers i.e. epicarp, mesocarp \& endocarp ( Plate 1 Fig. 1).

\section{Epicarp:}

Epicarp is soft $0.1 \mathrm{~mm}$ in thickness, with 1-2 layers of parenchymatous cells. It is bounded on the outer side by a single layered epidermis which is not ruptured ( Plate 1, Fig. 2). The cells appear well preserved and at places cells have disintegrated showing empty space between the epicarp and mesocarp. This indicates to the soft nature of the fruit.

\section{Mesocarp:}

It consists of thick walled polygonal compactly arranged sclerenchymatous cells. It is the broadest layer of the fruit wall ( Plate 1 Fig.4). The mesocarp measures about $2 \mathrm{~mm}$ in thicknes.

\section{Endocarp:}

It is the innermost layer of the fruit wall and is not well preserved; it is single layered $1 \mathrm{~mm}$ in thickness and made up of hard cells ( Plate 1 Fig. 1).

\section{Locule:}

Transverse section of fruit shows only one locule which is well preserved. The size of the locule is $2.8 \mathrm{~mm}$. There is only one seed in the locule. Therefore it is one seeded unilocular fruit

\section{Seed:}

The single nonendospermic seed measures 11 $\mathrm{mm} \times 18 \mathrm{~mm}$ in length and breadth. Seed occupies the entire space of the fruit and shows marginal placentation. The shape of seed is oval, fan shaped.

Seed Coat: The seed coat is undifferentiated.

\section{Discussion and Comparison}

The above description of the specimen reveals the following important characters for its identification.

1. Fruit is unilocular, single seeded

2. The fruit wall shows epicarp, mesocarp and endocarp
3. Seed coat undifferentiated, a characteristic feature of indehiscent fruit. (Corner 1976).

4. Fruit legume

5. $\quad$ Fruit indehiscent

6. Marginal placentation

From the above characters it can be concluded that the present fruit is unilocular showing single seed with marginal placentation. The fruit wall is well differentiated and hence Leguminous (Rendle 1956). Seed is in young developmental stage. It is very small and hemianatropus type (Maheshwari, P.1950). In present fruit the seed has undifferentiated seed coat. On the basis of above characters, it was compared with the reported fossil fruits.

Bicarpelocarpon singhpurii (Bhowal and Sheikh, 2008), is bilocular fruit reported from Shinghpur thereforeits different from present fruit. Portulacaceocarpon jamsavlli (Meshram, Narkhede and Bhowal, 2011), is unilocular fruit with free central placentation bt present fruit shows marginal placentation therefore it is different. Lagerstromiocarpon harissii ( Kokate 2013), is a multilocular fruit with axile placentation but present fruit unilocular with marginal pacentation therefore it is different fruit. Tiliaceaeocarpon jamsavlii ( Meshram, Narkhede and Bhowal, 2013), is a unilocular but placentation is different therefore it is different fruit. Pentaloculocarpon intertrappea (Khursel and Narkhede, 2016), is pentalocular fruit but placentation is not well explain therefore it is different fruit. Drupaceocarpon sahnii (Nandeshwar and Narkhede, 2016), is unilocular fruit with stalk and drupaceous nature but presen fruit is simple fruit with marginal placentaion. Portulacaceocarpon bhuterwncis (Borkar and Nagrale), fruit is multiseeded unilocular with free central placention, therefore it is different fruit. Tamaricaceocarpon mohgaonse, ( Yadav 
2017 ), fruit is unilocular but placentation is not well defined therefore present fruit is different.

Thus the above comparison of the fruit with earlier described fossil does not shows any resemblances as the specimen under study is very different, in the nature of fruit, fruit wall both morphologically and anatomically.

The present fossil fruit is then compared with modern fruits of different dicotyledonous families like, Primulaceae, Malpighiaceae, Cruciferae, Capparidaceae, Crassulaceae, Leguminosae (Bentham and Hooker, J. D. 1961, Hutchinson, J. 1959, Rendle, A. B. 1965, Bhojwani and Bhatnagar 1990, Bhttacharyya and Johri, 1998), because the fossil fruit shares some affinities with these families.

In family Primulaceae, ovule is hemianatropous, with Free central placentation, fruit is unilocular, seed with a small embryo surrounded by fleshy endosperm but in present case fruit is unilocular, ovule hemianatropous, placentation marginal therefore present fruit differs in with respect to the placentation type.

In family Malpighiaceae, ovule is hemianatropous, fruit is drupe or nut which divides into one seeded nut, but in present case there is no demarcation of drupaceous nature of fruit. Thus cannot be placed under this family.

In family Cruciferae, fruit is usually a siliqua, bilocular, with parietal placentation, ovule generally anatropous, but present fruit shows marginal placentation, unilocular, single seeded therefore it is different.

In family Capparidaceae, fruit unilocular, siliqua, with parietal placentation, ovule generally numerous and campylotropous but the present fruit shows marginal placentation, single seeded therefore it is totally different.

In family Leguminosae (Bentham and Hooker, J. D. 1961, Rendle, A. B. 1965, Hutchinson, J. 1959, Esau 1953 and 1970, Eames 1961 Fahn 1989), the typical fruit is a pod (legume), single or many seeded which dehises by both dorsal and ventral sutures, and has an elongated funicle. But in Hedysarum the pod, splits transversely into a number of indehiscent pieces which are forced open on germination by the swelling of the cotyledons and the elongation of the hypocotyls and then the fruit dehises. Some of the genera that resembles the present fruit are as follows :

In Entada, Mimosas, Desmodium, the pod is constricted between the seeds, forming a lomentum which does not dehisce but breaks into one-seeded joints.

In Astragalus it divides by a secondary (or false) longitudinal septum. The pod shows great variation in size and form; some measure only a fraction of an inch, other, like Entada gigas (Mimosoideae), are great woody structures more than a yard long and several inches wide. They are generally flattend but sometime round and rod-like, as in Cassia fistula. Some are more or less bent, or spirally coiled as in Medicago.

The tribe Dalbergieae (Papilionatae) is characterized by indehiscent pod which are often only one seeded and winged. In Colutea the pod is severeral-seeded and bursts under pressure; it becomes detached and is blown some distance before bursting, or breaks and scatters the seeds.

In Mimosoideae and Papilionatae endosperm is wanting or present in small quantity, generally filling up the space around the radical.

In Caesalpinioideae it may be absent or present in greater or less quantity, the tribe Bauhinieae a thin layer is formed round the embryo, while in the Cassieae it is copious and cartilaginous. The embryo is generally flat leaf like.

On the basis of above taxonomical and anatomical character it is clear that the fossil fruit shows resemblances with the family Leguminosae like characters unilocular, fruit dehiscent some times indehiscent, with marginal placentation. Fruit wall differentiated 
into epicarp, thick parenchymatous mesocarp and thin endocarp (Fahn 1989).

Hence it is named as Leguminoceocarpon singhpurii gen.et sp. nov. generic name is after the Leguminous nature of the fruit and specific name is come from new locality Singhpur

\section{Dignosis}

Leguminoceocarpon gen. nov.

Fruit spherical in shape, unilocular in condition, indehiscent, and simple, smooth pericarp differentiated into epicarp, thick parenchymatous mesocarp and thin endocarp. Seed single, marginal placentation with undifferentiated seed coat. Embryo not seen. Fruit legum.

Leguminoceocarpon singhpurii gen. et sp. nov.

Fruit dicotyledonous unilocular indehiscent, it is measured about $3.2 \mathrm{~mm}$ in diameter. Fruit wall $0.4 \mathrm{~mm}$ in thickness. Fruit wall differentiated into $0.1 \mathrm{~mm}$ thick epicarp, $0.2 \mathrm{~mm}$ thick mesocarp and $0.1 \mathrm{~mm}$ thick endocarp of hard cells. Locule $2.8 \mathrm{~mm}$ across in diameter. Sinlge seed $1.1 \mathrm{~mm} \times 1.8 \mathrm{~mm}$ in size, seed coat undifferentiated. Embryo not seen, endosperm present but not clearly seen.

Holotype: SMM / Dicot Uni. Fruit 4 / Deposited at Botany Department, Institute of Science, Nagpur.

Locatity : $\quad$ Singhpur, M.P., India

Hrizon : Decean Intertrappean series of Central India.

Age : Upper Cretaeceous.

\section{REFERENCES}

Bentham and Hooker, J. D. 1961. The flora of British India .Vol. II and III Recev. And Co. England.

Bhattachrya, B. and Johri, B. M. 1998. Flowering plants Taxanomy and
Phylogeny. Narosa Pub. House, New Delhi.

Bhojwani S and Bhatnagar S.P. 1990, The embryology of angiosperm, Vikas Publication House PVT LTD, New Delhi.

Bhowal M, and Sheikh M.T. 2008, A Petrified dicot fruit Bicarpelocarpon Singhpurii, From Deccan Intertrappean beds of Singhpur, M.P. India. Palaeobotanist $57(3): 473-441$

Borkar S.U. and Nagrale V. 2016. Taxonomical identification of a new petrified multiseeded capsular fruit from the Deccan Intertrappean beds of Bhutera, India. The Palaeobotanist 65(2016): $271-278$

Carter, H.J.(1857). Summary of the geology of India,between the Ganges, the Indus and Cape Comorin.J.Bom.R.Asiat.Soc. 5:179-180.

Corner, E. J. H. 1976. The seed of Dicotyledons Vol 1 and 2. Cambridge University press.

Eames, A. J. 1961. Morphology of the Angiosperms. Mcgraw Hill Book Companey, Inc. New York.

Esau, K. 1953. Plant Anatomy John Wiely \& Sons New York.

$>$ Esau. K. 1970. Anatomy of seed plants. John Wiely \& Sons.

Fahn A. J. 1989 Plant anatomy. Pergamon Press, Sydeny. 
Khursel A.S. And Narkhede,S.D. 2016. A new petrified pentalocular capsular fruit from the Deccan Intertrappean beds of Mohgaonkalan, M.P. India. Int.J.Curr.Microbiol.App.Sci.5(4): 483487

Nandeshvar M.P and Narkhede S.D. 2016. A Petrified Drupaceous fruit from the Deccan Intertrappean Beds of Singhpur, M.P. India.Gurukul International Multidisciplinary Research Journal. ISSN No. 23948426, 42-47

Hutchinson, J. 1959. The Families of Flowering Plants. Koeniqstein.

Kokate et al. (2013) A petrified capsular fruit Lagerstroemiocapon harrisii gen.et.sp. Geophytology 43(1):57-62

Maheshwari, P. 1950. An Introduction to embryology of angiosperms, Tata McGraw Hill Pub. Company Ltd., Bombay, New Delhi.

Meshram S. M., Narkhede, S. D. and Bhowal M. (2011).The taxonomic identification of unilocular angiospermic fruit from new locality Jamsavli, M.P. India. Bionanofrontear, Vol 4 (2), 344-346.

Meshram S.M., Narkhede. S.D. and Bhowal M. (2013). A new petrified unilocular fruit from the Deccan Intertrappean beds of Jamsavli M.P. India. Int.J.Of Life Sciences, Vol 1(3):221-225.

Rendle, A. B. 1956. Classification of flowering plants; Vol. I and II Cambridge Univ. Press, London.

Yadav

A. 2017. Tamariacaceocarpon mohgaonse gen,et sp.nov.from the Deccan Intertrappean beds of Mohgaonkalan, M.P.,India. Advances in Bioresearch., Vol 8(2) March 2017:196-200

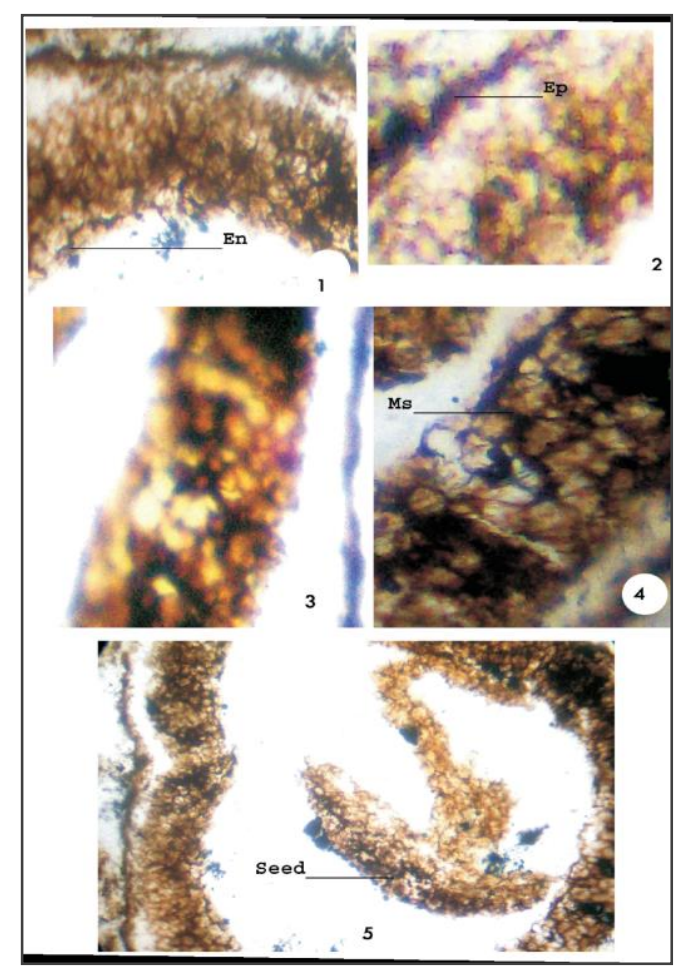

Plate No. 1 